\title{
Edible Coating for Beef Preservation from Chitosan Combined with Liquid Smoke
}

\author{
Hera Desvita ${ }^{1}$, Muhammad Faisal $^{2 *}$, Mahidin $^{2}$, Suhendrayatna $^{2}$ \\ ${ }^{1}$ Doctoral Program, School of Engineering, Universitas Syiah Kuala, Jalan Tengku Syech Abdur Rauf No. 7, \\ Darussalam, Banda Aceh 23111, Indonesia \\ ${ }^{2}$ Department of Chemical Engineering, Faculty of Engineering, Universitas Syiah Kuala, Jalan Tengku Syech \\ Abdur Rauf No.7, Darussalam, Banda Aceh 23111, Indonesia
}

\begin{abstract}
This study aims to determine the effectiveness of chitosan (ch) combined with liquid smoke (Ls) as an edible coating for beef preservation. The Ls used in this study was made from rice hulls pyrolyzed at temperatures of $300^{\circ} \mathrm{C}$ (T1), $340^{\circ} \mathrm{C}$ (T2), and $380^{\circ} \mathrm{C}$ (T3). An edible coating was made by dissolving ch levels of $0.5 \%, 1.0 \%$, and $1.5 \%$ (w/v) into $3 \%$ Ls. Preservation was accomplished by soaking the beef in an edible coating solution for 15 minutes and subsequently storing it in a refrigerator $\left(4-7^{\circ} \mathrm{C}\right)$; it was then observed every 24 hours. A food resistance test was carried out using the total volatile base nitrogen (TVB-N) and organoleptic (odor, color, and texture) tests. The odor value in the A4 sample (T1, 1.5\% ch) did not change after four days in storage. By comparison, the other samples changed on the third day. Observations revealed that the beef texture did not change until the fourth day in the A4 (T1, 1.5\% ch) and C4 (T3, 1.5\% ch) samples. Color changes occurred in all samples on the fourth day, but the panelists considered the color values in the $\mathrm{C} 4$ sample (pyrolysis temperature $380^{\circ} \mathrm{C}, 1.5 \% \mathrm{ch}$ ) to be acceptable until the ninth day. The quality of the beef that was only preserved with Ls decreased faster than those preserved using a combination of ch and Ls. The longer the storage time, the greater the produced TVB-N value, indicating a reduction in beef freshness. The TVB-N value of the beef preserved with a combination of ch and Ls was lower than the beef preserved without ch. The TVB-N values significantly increased after four days in storage. However, all samples remained fresh and met the Indonesian National Standard for meat freshness, wherein the TVB-N values do not exceed $0.20 \mathrm{mgN} / 100 \mathrm{~g}$, until the eighth day. The results revealed that edible coatings made from a combination of $\mathrm{ch}$ and Ls can serve as alternative beef preservatives.
\end{abstract}

Keywords: Chitosan; Edible coating; Liquid smoke; Rice hulls; Total volatile base

\section{Introduction}

Chitosan (ch)-based edible coatings have seen wide use as preservatives for raw materials, such as beef, poultry, and other processed meat products. As a natural and cheap biopolymer produced from chitin, ch is often used for edible coating. During the deacetylation process, chitin-derived ch from shrimp and crabs consists of $\beta-(1-4)-2$ acetamido-D-glucose and $\beta$-(1-4)-2-amino-D-glucose units with antifungal and antimicrobial properties that are useful as composite materials and in cosmetics,

${ }^{*}$ Corresponding author's email: mfaisal@unsyiah.ac.id, Tel.: +62-651-755222, Fax.: +62-651-755222 doi: 10.14716/ijtech.v11i4.4039 
biomedical fields, and food preservation (Abdou et al., 2008; Kusrini et al., 2014; Szymanska and Winnicka, 2015; HPS et al., 2016; Da silva Santos et al., 2017; Hanafiah et al., 2018). Ch possesses antibacterial and antioxidant properties that can be used as biodegradable packaging (Siripatrawan and Vitchayakitti., 2016).

In addition to its antibacterial properties, ch is stable, biodegradable, biocompatible, non-toxic, and relatively inexpensive (Ojagh et al., 2010; Balamurugan 2012; PérezCórdoba et al., 2018; Usman et al., 2018). Ch dissolves well in acidic compounds ( $\mathrm{pH}<6.0$ ) (Shariatinia, 2018) and does not dissolve in the neutral $\mathrm{pH}$ range. These properties make ch particularly suitable for the formulation of edible coatings. Thus far, the solvents used in ch include organic acids, such as formic acid, acetic acid, lactate, citric, and succinate, as well as inorganic solvents, including hydrochloric acid, nitrate, and phosphorus. Using $2.0 \%$ ch with the addition of $1.0 \%$ acetic acid can provide a strong barrier to oxygen, higher tensile strengths, and lower elongation, prolonging the shelf lives of sausages (Adzaly et al., 2016). Other, cheaper acid compounds can be used as alternatives to dissolve ch.

Liquid smoke (Ls) can be produced from biomass materials, such as rice hulls, by using the pyrolysis method (Abdullah et al., 2017). In recent years, rice hulls have primarily been used for silica (Dhaneswara et al., 2020), ash (Ramadhansyah et al., 2011), and exothermic material (Idamayanti et al., 2020). Ls has an acidic $\mathrm{pH}$ and can serve as a substitute for the more popular acetic acid. In addition to containing acetic acid, Ls comprises phenol compounds that have antibacterial and antioxidant properties (Faisal et al., 2017) that can replace glacial acetic acid. Ls can affect the odors, textures, colors, tastes, and shelf lives of food products. The low $\mathrm{pH}$ and phenol compounds in Ls can also damage bacterial cells and inhibit bacterial growth. Edible coatings have been produced by combining ch with various natural ingredients, such as mint (Kanatt et al., 2008), calcium gluconate (Hernandez-Munoz et al., 2008), rosemary extract (Xiao et al., 2010), cassava starch (Araújo et al., 2018), tapioca (Vásconez et al., 2009; Pratama et al., 2019), gelatin (Kumar et al., 2018; Yi et al., 2018), green tea extract (Apriyanti et al., 2018), spermidine, and glycerol (Sabbah et al., 2019). The combination of Ls and ch as an edible coating that is safe for health can also be used as an alternative natural preservative for maintaining the quality of food products.

Edible coatings from ch and Ls have frequently been developed in the food industry, especially for processed meat products (Kanatt et al., 2008). Meats contain complete nutrients, but their quality can decrease due to chemical, microbiological, and physical processes. High protein levels in meat can easily undergo lipid oxidation, which causes decay due to pathogenic microorganisms. Meat preservation is usually carried out by adding natural preservatives, such as garlic (Rakshit and Ramalingam., 2013), eugenol from cloves (Roller et al., 2002), turmeric starch, and gelatin (Tosati et al., 2018) or by freezing, irradiation, cooling technology, and packaging (Zhou et al., 2010). Few studies have investigated edible coatings for food preservation that use both Ls and ch. Strawberries' shelf lives can be extended to 6 days in the refrigerator $\left(10^{\circ} \mathrm{C}\right)$ using $1.0 \% \mathrm{ch}$ and $1.5 \%$ calcium gluconate as preservatives (Hernandez-Munoz et al., 2008), and sausages' shelf lives can be maintained for up to 15 days in the refrigerator using ch as a preservative (Roller et al., 2002). Edible coatings to preserve beef have already been created from ch and Ls derived from palm shells (Faisal et al., 2019). While adding 3.0\% Ls from palm shells with $1.0 \% \mathrm{ch}$ to meat preserves its taste, odor, and texture so that it is acceptable to consumers six days after storage (Hanafiah et al., 2018), tofu and meatballs can be preserved for three days through a combination of $1.5 \%$ Ls and $2.5 \%$ ch (Purba et al., 2014). The combination of ch and Ls from rice hulls can serve as an alternative beef 
preservative. This study aims to determine the feasibility of using ch and Ls from rice hulls as a natural preservative for beef in cold storage.

\section{Methods}

\subsection{Tools and Materials}

The tools in this study included a pyrolysis reactor (locally designed) made of stainless steel with a capacity of $5 \mathrm{~kg}$ (diameter $=40 \mathrm{~cm}$, height $=60 \mathrm{~cm}$ ) and a series of distillation devices that included a distillation flask (Iwaky-Pyrex). The materials used in this study consisted of rice hulls, ch from shrimp skin (Chitosan Pharmaceutical Medical Grade, CV. Chimultiguna, Indonesia), 96\% ethanol (Brataco, Indonesia), potassium carbonate (KGAa, Germany), boric acid (KGAa, Germany), 7.0\% trichloroacetic acid (TCA) (KGAa, Germany), 38\% hydrochloric acid (Merck, USA), and a phenolphthalein indicator (Merck, USA).

\subsection{Preparation of Liquid Smoke}

The raw materials of rice hulls were dried in the sun for two days. To start, $3 \mathrm{~kg}$ of raw materials were put into the pyrolysis reactor and then hydrolyzed at temperatures of $300^{\circ} \mathrm{C}, 340^{\circ} \mathrm{C}$, and $380^{\circ} \mathrm{C}$ for roughly 2 hours to produce smoke, which was then condensed to produce Grade $3 \mathrm{Ls}$, tar, and charcoal using the methodology of a previous study (Faisal et al., 2018). Figure 1 shows a schematic illustration for the production of Ls. Ls was purified by distillation at $190^{\circ} \mathrm{C}$ in order to produce food grade Ls and separate the tar.

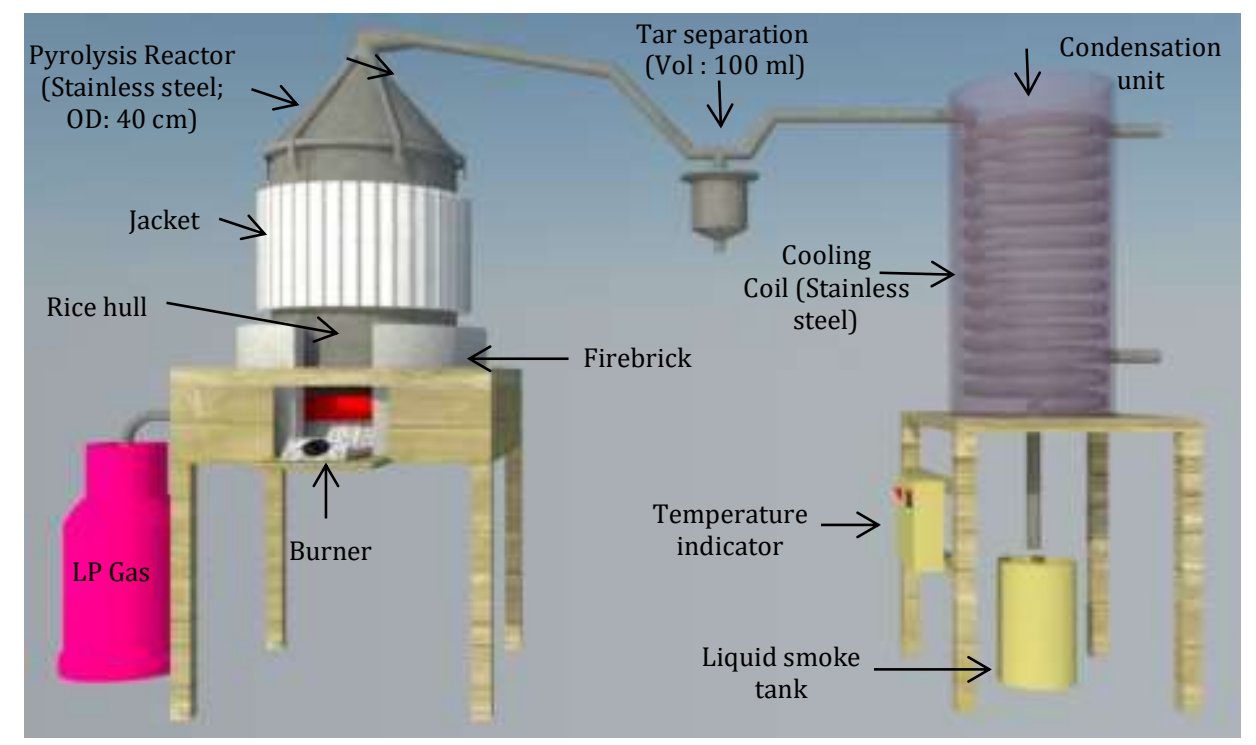

Figure 1 Schematic illustration for the production of liquid smoke

\subsection{Preparation of Edible Coating}

Ch of various weights $(\mathrm{kg})$ was added to $3.0 \% \mathrm{Ls}$. As in a previous study (Hanafiah et al., 2018), it was then stirred using a magnetic stirrer (IKA C-Mag HS 7) for 30 minutes at a temperature of $50^{\circ} \mathrm{C}$ to produce a homogeneous mixture. The symbols for each combination of ch and Ls are presented in Table 1. Prior research (Usman et al., 2018; Kusrini et al., 2015) was used to determine ch concentrations $(<2$ g). The schematic illustration for the edible coating's preparation is shown in Figure 2. The Ls this study used was produced from the pyrolysis of rice hulls at various temperatures. The beef was cleaned and thinly sliced along the muscle tissue at $5 \mathrm{~g}$ each. It was then soaked into an edible coating solution for 15 minutes, stored in a refrigerator, and observed every 24 
hours. The beef's resistance to decay was determined by observing organoleptic (odor, texture, and color) and total volatile base nitrogen (TVB-N) parameters.

\subsection{Organoleptic test}

Organoleptic testing uses human sensory organs to test food and includes examining texture with the hands or tongue, food color using the eyes, and food smell with the nose. In this study, organoleptic tests were carried out using the same method described in a previous study (Faisal et al., 2019).

The average quality score was calculated as follows:

$$
\mathrm{x}=\frac{\Sigma x i}{n}
$$

where $x$ is the average quality score, $x i$ is the organoleptic score of panelist $i$, and $n$ is the number of panelists.

Table 1 Proportions of chitosan and liquid smoke for edible coating

\begin{tabular}{ccc}
\hline Symbol & Liquid smoke & Chitosan (\%) \\
\hline A1 & T1 & 0 \\
A2 & T1 & 0.5 \\
A3 & T1 & 1.0 \\
A4 & T1 & 1.5 \\
B1 & T2 & 0 \\
B2 & T2 & 0.5 \\
B3 & T2 & 1.0 \\
B4 & T2 & 1.5 \\
C1 & T3 & 0 \\
C2 & T3 & 0.5 \\
C3 & T3 & 1.0 \\
C4 & T3 & 1.5 \\
\hline
\end{tabular}

Note: The study used Ls obtained from the pyrolysis of rice hulls at different temperatures, which are represented as follows: $\mathrm{T}_{1}=300^{\circ} \mathrm{C}, \mathrm{T}_{2}=340^{\circ} \mathrm{C}$, and $\mathrm{T}_{3}=380^{\circ} \mathrm{C}$

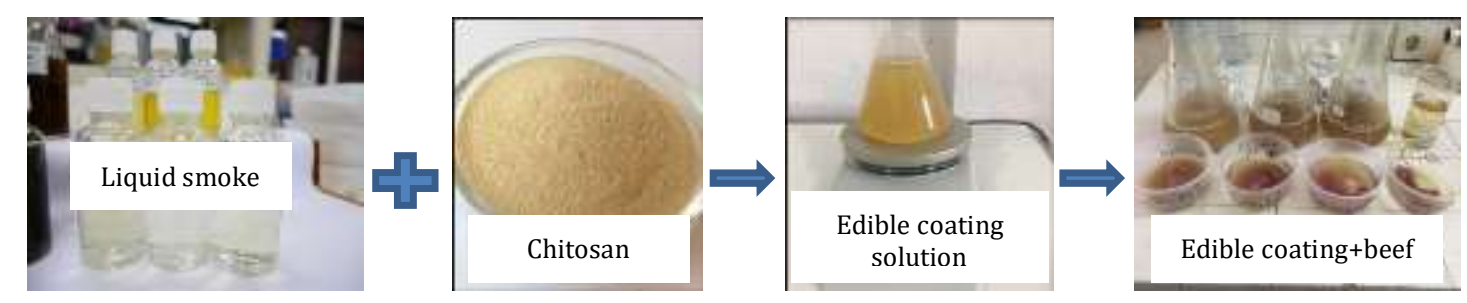

Figure 2 Schematic illustration for the preparation of edible coating

\subsection{TVB- $N$ test}

The TVB-N measurement is used to determine the freshness of beef according to the accumulation of basic compounds, such as ammonia, trimethylamine, and other volatile compounds that evaporate. Beef freshness can be determined through the TVB-N value. The TVB-N value is higher when the quality of beef is lower. The TVB-N test seeks to determine the amount of content that is present in volatile acidic/basic compounds due to protein degradation (Botta et al., 1984).

This study used beef sliced to $5 \mathrm{~g}$ with the addition of $15 \mathrm{ml}$ of $7.0 \%$ TCA solution that was homogenized for 1 minute. The solution was filtered and placed in the outer chamber of a Conway dish, and $1 \mathrm{ml}$ of boric acid solution was put into the inner chamber of the Conway dish. With the Conway dish almost closed, $1 \mathrm{ml}$ of $\mathrm{K}_{2} \mathrm{CO}_{3}$ was added to the outer 
chamber. The dish was then closed tightly using Vaseline as an adhesive and shaken for one minute. The sample was incubated for 2 hours at $35^{\circ} \mathrm{C}$. After incubation, the sample was titrated with HCL $0.1 \mathrm{~N}$ (Faisal et al., 2018).

\section{Results and Discussion}

\subsection{Organoleptic test}

\subsubsection{Odor}

Adding $0.5-1.5 \%$ ch to Ls affected the beef's odor in storages of $4-7^{\circ} \mathrm{C}$. The results of the observations are presented in Table 2.

Table 2 Hedonic test values for the odor of the beef preserved with various concentrations of chitosan and liquid smoke

\begin{tabular}{cccccccccccc}
\hline & \multirow{8}{*}{$\begin{array}{c}\text { Chitosan } \\
\text { Symbol }\end{array}$} & \multicolumn{10}{c}{ Odor Value } \\
\cline { 3 - 12 } & 0 & 0 & 1 & 2 & 3 & 4 & 5 & 6 & 7 & 8 & 9 \\
\hline $\mathrm{A}_{1}$ & 0 & 5.0 & 5.0 & 4.9 & 4.7 & 4.1 & 3.5 & 2.7 & 2.1 & 1.7 & 1.0 \\
$\mathrm{~A}_{2}$ & 0.5 & 5.0 & 5.0 & 5.0 & 5.0 & 4.8 & 4.0 & 3.0 & 2.0 & 1.8 & 1.0 \\
$\mathrm{~A}_{3}$ & 1.0 & 5.0 & 5.0 & 5.0 & 5.0 & 4.7 & 3.7 & 3.1 & 2.4 & 2.3 & 1.7 \\
$\mathrm{~A}_{4}$ & 1.5 & 5.0 & 5.0 & 5.0 & 5.0 & 5.0 & 4.2 & 3.6 & 3.1 & 2.6 & 1.7 \\
$\mathrm{~B}_{1}$ & 0 & 5.0 & 5.0 & 5.0 & 4.9 & 4.2 & 3.5 & 3.0 & 2.0 & 1.6 & 1.0 \\
$\mathrm{~B}_{2}$ & 0.5 & 5.0 & 5.0 & 5.0 & 5.0 & 4.4 & 3.0 & 2.1 & 2.0 & 1.3 & 1.0 \\
$\mathrm{~B}_{3}$ & 1.0 & 5.0 & 5.0 & 5.0 & 5.0 & 4.7 & 3.1 & 3.0 & 3.0 & 2.9 & 1.4 \\
$\mathrm{~B}_{4}$ & 1.5 & 5.0 & 5.0 & 5.0 & 5.0 & 4.8 & 4.3 & 4.0 & 3.0 & 2.1 & 1.5 \\
$\mathrm{C}_{1}$ & 0 & 5.0 & 5.0 & 5.0 & 5.0 & 4.4 & 4.0 & 3.8 & 3.0 & 1.9 & 1.0 \\
$\mathrm{C}_{2}$ & 0.5 & 5.0 & 5.0 & 5.0 & 5.0 & 4.3 & 4.2 & 4.1 & 2.9 & 2.2 & 1.2 \\
$\mathrm{C}_{3}$ & 1.0 & 5.0 & 5.0 & 5.0 & 5.0 & 4.9 & 4.7 & 4.1 & 3.3 & 2.4 & 1.6 \\
$\mathrm{C}_{4}$ & 1.5 & 5.0 & 5.0 & 5.0 & 5.0 & 4.9 & 4.7 & 4.2 & 3.6 & 2.7 & 1.8 \\
\hline
\end{tabular}

Notes: 1 = Very smelly; 2 = Smelly; 3 = Fairly smelly; 4 = Quite smelly; 5 = Not smelly

Table 2 shows that the combinations of ch and Ls resulted in different odor changes depending on storage time. The panelists preferred the A4 sample's odor because its score was still 5.0 on day four and they found its smell acceptable until day eight. The odor values decreased with storage time. In other words, the odor scores decreased when the storage time was longer. While samples A2-A4 retained scores of 5.0 until day three, the odor scores for the sample without ch (A1) decreased by day two. Nonetheless, the panelists considered the odor for A1 to be acceptable until day six. The panelists found that the odor values for samples A2 and A3 were acceptable until day six. The best conditions were represented by sample A4, whose odor remained good until day eight. Due to the decay that occurs in beef, longer storage times lead to lower odor scores. Samples with $3.0 \%$ Ls and $1.0-1.5 \%$ ch had pleasant odors after seven days in storage (Hanafiah et al., 2018). The produced odors were influenced by the oxidation of fatty acids that produce peroxide and hydroperoxide compounds (Botta et al., 1984).

The panelists preferred the odor of the B3 beef. Although the odor score for the B1 sample started to decrease on day three, it remained acceptable until day seven. The odor values decreased with storage time. The B2-B4 samples retained their good odors until day three. By day eight, the only sample with an acceptable odor was B3 with a score of 2.9. The B4 sample had the highest odor score on each observed day. Odor score values were better for longer periods of storage time when the concentrations of ch were higher. A study by Purba et al. (2014) revealed that using 2.5\% ch to preserve meatballs made it so the odor did not change for three days in refrigerated storage. 
Adding high concentrations of ch can slow the development of poor odors in beef during storage. Table 2 shows that the $\mathrm{C} 1-\mathrm{C} 4$ samples did not undergo odor changes until day three. While the panelists considered the odors for the C1 and C2 to be unacceptable by day seven, they found the odors of the C3 and C4 samples to be acceptable by that same time. On day eight, the beef had produced a bad odor and was not suitable for consumption. By comparison, fish that have been preserved using Ls from durian skin have lasted up to 48 hours at room temperature (Faisal et al., 2019). In Saloko et al. (2014) study, the use of Ls and 1.5\% ch maintained the freshness and odor of tuna for 24 hours at room temperature.

\subsubsection{Texture}

To examine beef texture, texture checking is carried out by hand. As shown in Table 3, although the texture of the A4 sample was well preserved until day six, the textures for the A1-A3 samples were only sustained until day five. According to Table 3, the texture of the B4 sample was slightly hard until day six. On that same day, the textures of the B1-B3 samples began to soften. The panelists considered the samples' textures to be unacceptable by day seven. The best textures were recorded on day six for the C2-C4 samples and day five for the $\mathrm{C} 1$ sample. The panelists considered the $\mathrm{C} 4$ sample to be in the best condition, as they liked the beef's slightly firm texture. Overall, the meat remained firm from days zero to three, and the texture score began to decline by day four of storage. Adding high concentrations of ch to beef can produce antimicrobial films that extend the shelf life of beef. A previous study confirmed that using starch and ch at a ratio of 70:30 can extend the shelf life of meat to three days in the refrigerator (Valencia-Sullca et al., 2018).

Table 3 Hedonic test value for the texture of beef preserved with various concentrations of chitosan and liquid smoke

\begin{tabular}{cccccccccccc}
\hline & \multirow{8}{*}{$\begin{array}{c}\text { Chitosan } \\
\text { Symbol }\end{array}$} & \multicolumn{10}{c}{ Day } \\
\cline { 3 - 12 } & & 0 & 1 & 2 & 3 & 4 & 5 & 6 & 7 & 8 & 9 \\
\hline $\mathrm{A}_{1}$ & 0 & 5.0 & 5.0 & 5.0 & 5.0 & 4.5 & 4.0 & 3.1 & 2.5 & 2.0 & 1.1 \\
$\mathrm{~A}_{2}$ & 0.5 & 5.0 & 5.0 & 5.0 & 5.0 & 4.9 & 4.0 & 3.1 & 2.1 & 1.8 & 1.0 \\
$\mathrm{~A}_{3}$ & 1.0 & 5.0 & 5.0 & 5.0 & 5.0 & 4.7 & 3.4 & 3.1 & 2.5 & 2.4 & 1.8 \\
$\mathrm{~A}_{4}$ & 1.5 & 5.0 & 5.0 & 5.0 & 5.0 & 5.0 & 4.2 & 3.7 & 2.9 & 2.0 & 1.6 \\
$\mathrm{~B}_{1}$ & 0 & 5.0 & 5.0 & 5.0 & 5.0 & 4.5 & 3.5 & 3.0 & 2.1 & 1.7 & 1.0 \\
$\mathrm{~B}_{2}$ & 0.5 & 5.0 & 5.0 & 5.0 & 5.0 & 4.5 & 3.1 & 2.2 & 2.0 & 1.3 & 1.0 \\
$\mathrm{~B}_{3}$ & 1.0 & 5.0 & 5.0 & 5.0 & 5.0 & 4.8 & 3.1 & 3.0 & 3.0 & 2.9 & 1.6 \\
$\mathrm{~B}_{4}$ & 1.5 & 5.0 & 5.0 & 5.0 & 5.0 & 4.8 & 4.3 & 4.0 & 3.1 & 2.1 & 1.5 \\
$\mathrm{C}_{1}$ & 0 & 5.0 & 5.0 & 5.0 & 5.0 & 4.5 & 4.1 & 3.8 & 3.1 & 2.0 & 1.1 \\
$\mathrm{C}_{2}$ & 0.5 & 5.0 & 5.0 & 5.0 & 5.0 & 4.4 & 4.1 & 4.1 & 3.0 & 2.3 & 1.3 \\
$\mathrm{C}_{3}$ & 1.0 & 5.0 & 5.0 & 5.0 & 5.0 & 4.9 & 4.6 & 4.1 & 3.4 & 2.6 & 1.9 \\
$\mathrm{C}_{4}$ & 1.5 & 5.0 & 5.0 & 5.0 & 5.0 & 5.0 & 4.6 & 4.1 & 3.6 & 2.7 & 1.8 \\
\hline
\end{tabular}

Notes: $1=$ Squishy; 2 = Soft; 3 = A bit firm; 4 = Quite firm; 5 = Firm

\subsubsection{Color}

The addition of ch significantly affected the beef's color. Ch in high concentrations made the color of the beef's surface redder. Beef is considered to be in good condition if its color is bright red (Indonesian National Standard, 2008). The results of the observation of the beef's color changes during storage are presented in Table 4. The use of Ls in various conditions and concentrations of ch did not significantly affect the beef's coloration. The results of the observation show that the same score (i.e., 5.0) was given to all the samples from day one to day four. Table 4 shows that the A1-A4 samples remained bright red until 
day seven, indicating that the beef was still good. While sample B4 had the best conditions by day seven, the B1-B3 samples were bright red until day six. Furthermore, the C4 sample was bright red until day nine, and the C1-C3 samples were bright red until day eight. In a study by Robledo et al. (2018), the use of $2.0 \%$ ch in strawberries maintained their red color until their fifth day of storage in the refrigerator. Changes in color can be caused by lactic acid bacteria that produces hydrogen peroxide during the storage process or be attributed to the oxidation of myoglobin due to lipid oxidation (Cayre et al., 2005). In Faisal et al. (2019) study, the use of $0.5-3.0 \%$ Ls to preserve fish produced positive results, possibly due to the high content of phenol and acetic acid, which kept the fish fresh. The fish's color only began to change after 42 hours of soaking at room temperature. This particular color change is associated with the Maillard reaction between the carbonyl group and ch amino group (Valencia-Sullca et al., 2018). The intensity of discoloration in the samples was indicative of the presence of the melanoidin pigment from the Maillard reaction (Geng et al., 2019).

Table 4 Hedonic test value for the color of beef preserved with various concentrations of chitosan and liquid smoke

\begin{tabular}{cccccccccccc}
\hline & \multirow{2}{*}{$\begin{array}{c}\text { Chitosan } \\
\text { Symbol }\end{array}$} & \multicolumn{10}{c}{ Color Value } \\
\cline { 3 - 12 } & & 0 & 1 & 2 & 3 & 4 & 5 & 6 & 7 & 8 & 9 \\
\hline $\mathrm{A}_{1}$ & 0 & 5.0 & 5.0 & 5.0 & 5.0 & 5.0 & 4.8 & 4.0 & 3.6 & 2.4 & 2.0 \\
$\mathrm{~A}_{2}$ & 0,5 & 5.0 & 5.0 & 5.0 & 5.0 & 5.0 & 4.9 & 4.0 & 3.6 & 2.4 & 1.9 \\
$\mathrm{~A}_{3}$ & 1.0 & 5.0 & 5.0 & 5.0 & 5.0 & 5.0 & 4.8 & 4.0 & 3.0 & 2.9 & 2.3 \\
$\mathrm{~A}_{4}$ & 15 & 5.0 & 5.0 & 5.0 & 5.0 & 5.0 & 4.9 & 4.4 & 3.7 & 2.9 & 2.4 \\
$\mathrm{~B}_{1}$ & 0 & 5.0 & 5.0 & 5.0 & 5.0 & 5.0 & 4.7 & 3.4 & 3.0 & 2.4 & 1.9 \\
$\mathrm{~B}_{2}$ & 0.5 & 5.0 & 5.0 & 5.0 & 5.0 & 5.0 & 4.7 & 3.4 & 2.6 & 2.0 & 1.9 \\
$\mathrm{~B}_{3}$ & 1.0 & 5.0 & 5.0 & 5.0 & 5.0 & 5.0 & 4.8 & 3.4 & 3.0 & 3.0 & 2.7 \\
$\mathrm{~B}_{4}$ & 1.5 & 5.0 & 5.0 & 5.0 & 5.0 & 5.0 & 4.9 & 4.4 & 4.0 & 3.4 & 2.6 \\
$\mathrm{C}_{1}$ & 0 & 5.0 & 5.0 & 5.0 & 5.0 & 5.0 & 4.9 & 4.4 & 3.9 & 3.0 & 2.6 \\
$\mathrm{C}_{2}$ & 0.5 & 5.0 & 5.0 & 5.0 & 5.0 & 5.0 & 4.9 & 4.5 & 4.0 & 3.4 & 2.6 \\
$\mathrm{C}_{3}$ & 1.0 & 5.0 & 5.0 & 5.0 & 5.0 & 5.0 & 4.9 & 4.5 & 4.5 & 3.4 & 2.7 \\
$\mathrm{C}_{4}$ & 1.5 & 5.0 & 5.0 & 5.0 & 5.0 & 5.0 & 4.9 & 4.5 & 4.5 & 3.5 & 3.0 \\
\hline
\end{tabular}

Notes: 1 = pale red $\amalg ; 2$ = light red $\leftleftarrows$; 3 = bright red $\square ; 4=$ blood red $\square ; 5=$ dark red

\subsection{TVB-N Results}

TVB-N is an indicator that is used to determine the damage to meat associated with enzyme and bacterial activity. Figures 3-5 present the results of the TVB-N analysis of beef over eight days of storage. TVB-N values are lower when there is a higher concentration of ch. The maximum TVB-N value for consumable beef is $0.20 \mathrm{mgN} / 100 \mathrm{~g}$ (Pearson, 1968). Preliminary observations indicated that the A1, B1, and C1 sampleswhich lacked the addition of ch-had TVB-N values of $0.024 \mathrm{mgN} / 100 \mathrm{~g}, 0.023 \mathrm{mgN} / 100 \mathrm{~g}$, and $0.023 \mathrm{mgN} / 100 \mathrm{~g}$, respectively. According to the Figures 3-5, the A1, B1, and C1 samples were not suitable for consumption because their TVB-N values were greater than $0.20 \mathrm{mgN} / 100 \mathrm{~g}$ on day nine. Overall, the TVB-N values did not significantly increase until day three. 


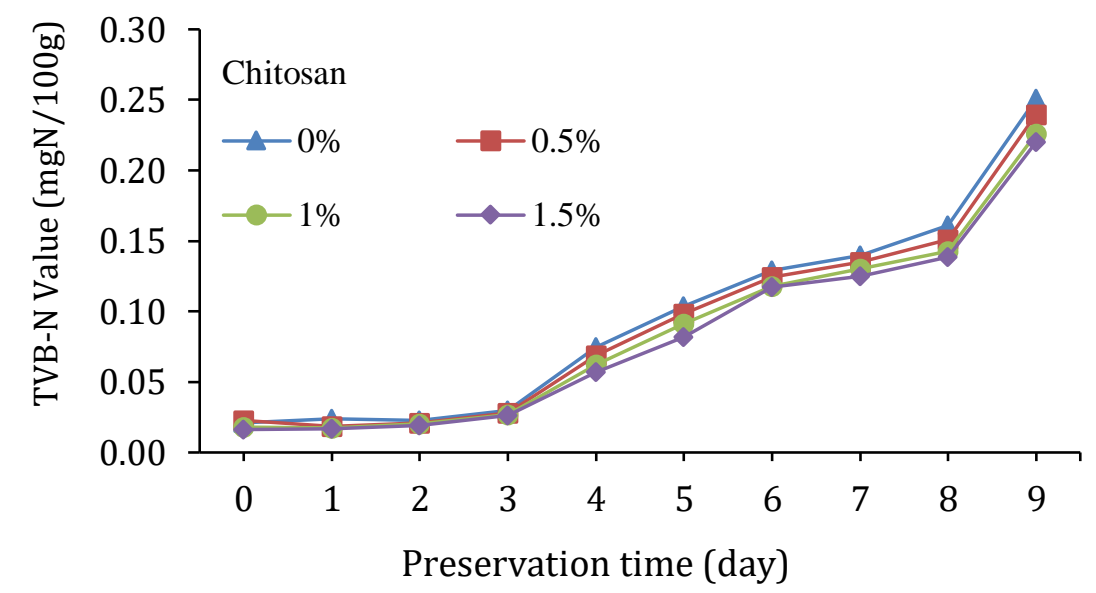

Figure 3 Effect of storage time on TVB-N values of beef preserved with chitosan and T1

As illustrated in Figure 3, the A2, A3, and A4 samples remained suitable for consumption on day four with TVB-N values of $0.047 \mathrm{mgN} / 100 \mathrm{~g}, 0.040 \mathrm{mgN} / 100 \mathrm{~g}$, and $0.039 \mathrm{mgN} / 100 \mathrm{~g}$, respectively. While the TVB-N values did not reach $0.1 \mathrm{mgN} / 100 \mathrm{~g}$ after three days of storage, they tripled by day five, with the A2-A4 samples reaching 0.087 $\mathrm{mgN} / 100 \mathrm{~g}, 0.080 \mathrm{mgN} / 100 \mathrm{~g}$, and $0.075 \mathrm{mgN} / 100 \mathrm{~g}$, respectively and the A1 sample (without the addition of $\mathrm{ch}$ ) reaching $0.090 \mathrm{mgN} / 100 \mathrm{~g}$. The TVB-N values slowly increased after five days of storage and did not exceed the maximum limit until day eight, when they reached $0.173 \mathrm{mgN} / 100 \mathrm{~g}, 0.152 \mathrm{mgN} / 100 \mathrm{~g}, 0.147 \mathrm{mgN} / 100 \mathrm{~g}$, and 0.139 mgN/100g. The TVB-N values exceeded the maximum limit after that point. In a previous study that used Ls for tofu preservation (Ginayanti et al., 2015), the tofu was found to be suitable for consumption for up to 60 hours (with a TVB-N value of $19.61 \mathrm{mgN} / 100 \mathrm{~g}$ ).

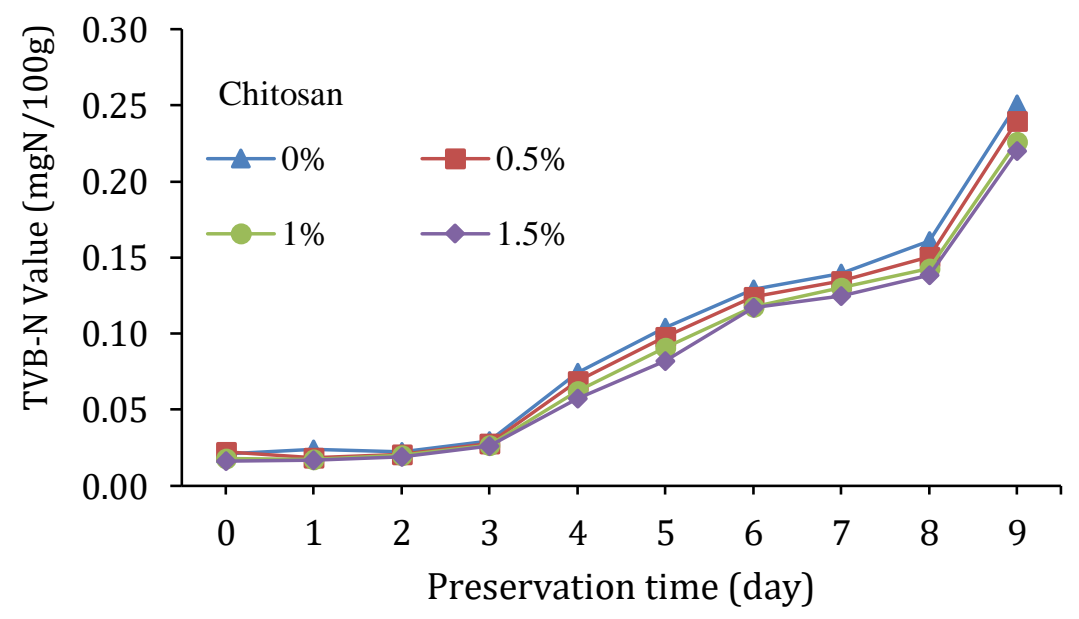

Figure 4 Effect of storage time on TVB-N values of beef preserved with chitosan and T2

Figure 4 shows that samples B1-B4 passed the threshold for consumption on day nine with TVB-N values of $0.251 \mathrm{mgN} / 100 \mathrm{~g}, 0.240 \mathrm{mgN} / 100 \mathrm{~g}, 0.226 \mathrm{mgN} / 100 \mathrm{~g}$, and 0.220 mgN/100g, respectively. By comparison, the TVB-N values for these samples at the beginning of the preservation were $0.023 \mathrm{mgN} / 100 \mathrm{~g}, 0.021 \mathrm{mgN} / 100 \mathrm{~g}, 0.018 \mathrm{mgN} / 100 \mathrm{~g}$, and $0.016 \mathrm{mgN} / 100 \mathrm{~g}$. The TVB-N values increased almost eightfold on day four with values of $0.075 \mathrm{mgN} / 100 \mathrm{~g}, 0.069 \mathrm{mgN} / 100 \mathrm{~g}, 0.062 \mathrm{mgN} / 100 \mathrm{~g}$, and $0.057 \mathrm{mgN} / 100 \mathrm{~g}$. In addition, day five's TVB-N values were $0.104 \mathrm{mgN} / 100 \mathrm{~g}, 0.098 \mathrm{mgN} / 100 \mathrm{~g}, 0.091$ 
$\mathrm{mgN} / 100 \mathrm{~g}$, and $0.082 \mathrm{mgN} / 100 \mathrm{~g}$. The meat samples also maintained good freshness by day eight, with TVB-N values that had not yet reached $0.20 \mathrm{mgN} / 100 \mathrm{~g}$.

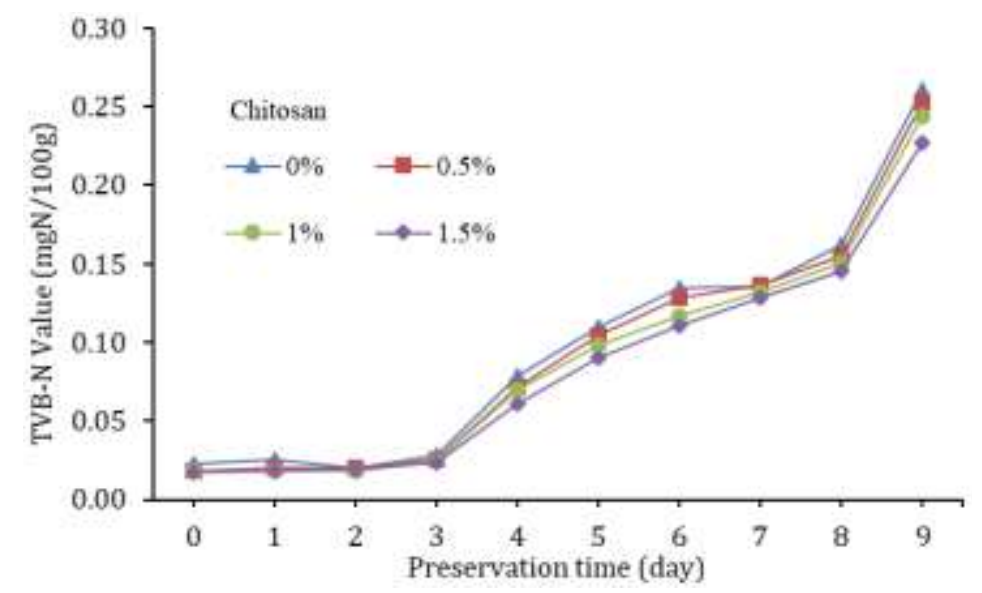

Figure 5 Effect of storage time on TVB-N values of beef preserved with chitosan and T3

According to Figure 5, the TVB-N values for the C1-C4 samples at the start of the preservation were $0.023 \mathrm{mgN} / 100 \mathrm{~g}, 0.018 \mathrm{mgN} / 100 \mathrm{~g}, 0.018 \mathrm{mgN} / 100 \mathrm{~g}$, and 0.017 $\mathrm{mgN} / 100 \mathrm{~g}$, respectively. After 24 hours, these TVB-N values increased to 0.025 $\mathrm{mgN} / 100 \mathrm{~g}, 0.020 \mathrm{mgN} / 100 \mathrm{~g}, 0.018 \mathrm{mgN} / 100 \mathrm{~g}$, and $0.018 \mathrm{mgN} / 100 \mathrm{~g}$. The TVB-N values did not reach $0.1 \mathrm{mgN} / 100 \mathrm{~g}$ by day four. However, on day six, the TVB-N values almost doubled, and they increased by $50 \%$ on day nine. The TVB-N values increased due to increases in trimethylamine from bacterial decomposition and ammonia from the degradation of amino acid (Jinadasa, 2014). The beef samples remained fresh until day eight. TVB-N values are lower when higher concentrations of ch are used. The addition of ch can reduce bacteria's ability to perform oxidative deamination in non-protein nitrogen compounds (Morachis-Valdez et al., 2017). Previous studies have indicated that Ls from durian skin with concentrations of $0.5-3 \%$ can enable fish to maintain its freshness for up to 60 hours Faisal et al. (2019). Using concentrations of 3\% Ls in meatball preservative can help to maintain their freshness for up to 15 hours of immersion at a TVB-N value of 12.6 mgN/100g (Botta et al., 1984). Edible coatings that use a combination of ch and Ls positively impact fish preservation by reducing the TVB-N value by $50 \%$ and are superior to preservation methods that only use Ls (Da Silva Santos et al., 2017). Souza et al. (2010) produced similar results, showing a 33-50\% reduction in the TVB values of salmon coated in ch.

\section{Conclusions}

The present study's results indicated that edible coatings of Ls from rice hulls that have been modified with ch can be used as natural preservatives for beef. Edible coatings can extend shelf life and affect organoleptic and TVB-N values. Beef quality decreased four days after storage, regardless of whether ch had been added. Beef with ch had a longer shelf life and better organoleptic and TVB-N values than the samples without ch. Ch concentrations affected beef preservation and its organoleptic values. Beef preserved with $1.5 \% \mathrm{ch}$ had the best organoleptic values of the observed samples, and it remained fresh up to eight days after the beginning of storage. 


\section{Acknowledgements}

The authors would like to thank the Ministry of Education and Culture of Indonesia and Universitas Syiah Kuala for funding this work.

\section{References}

Abdou, E.S., Nagy, K.S., Elsabee, M.Z., 2008. Extraction and Characterization of Chitin and Chitosan from Local Sources. Bioresource Technology, Volume 99(5), pp. 1359-1367

Abdullah, N.A., Putra, N., Hakim, I.I., Koestoer, R.A., 2017. A Review of Improvements to the Liquid Collection System Used in the Pyrolysis Process for Producing Liquid Smoke. International Journal of Technology, Volume 8(7), pp. 1197-1206

Adzaly, N.Z., Jackson, A., Kang, I., Almenar, E., 2016. Performance of a Novel Casing Made of Chitosan Under Traditional Sausage Manufacturing Conditions. Meat Science, Volume 113, pp. 116-123

Apriyanti, D., Rokhati, N., Mawarni, N., Khoiriyah, Z., Istirokhatun, T., 2018. Edible Coating from Green Tea Extract and Chitosan to Preserve Strawberry (Fragaria vesca L.). In: MATEC Web of Conferences, Volume 156, pp. 1-5

Araújo, J.M.S., de Siqueira, A.C.P., Blank, A.F., Narain, N., de Aquino Santana, L.C.L., 2018. A Cassava Starch-Chitosan Edible Coating Enriched with Lippia sidoides Cham. Essential Oil and Pomegranate Peel Extract for Preservation of Italian Tomatoes (Lycopersicon esculentum Mill.) Stored at Room Temperature. Food and Bioprocess Technology, Volume 11(9), pp. 1750-1760

Balamurugan, M., 2012. Chitosan: A Perfect Polymer Used in Fabricating Gene Delivery and Novel Drug Delivery Systems. International Journal of Pharmacy and Pharmaceutical Sciences, Volume 4(3), pp. 54-56

Botta, J.R., Lauder, J.T., Jewer, M.A., 1984. Effect of Methodology on Total Volatile Basic Nitrogen (TVB-N) Determination as an Index of Quality of Fresh Atlantic Cod (Gadus morhua). Journal of Food Science, Volume 49(3), pp. 734-736

Cayre, M.E., Garro, O., Vignolo, G., 2005. Effect of Storage Temperature and Gas Permeability of Packaging Film on the Growth of Lactic Acid Bacteria and Brochothrix thermosphacta in Cooked Meat Emulsions. Food Microbiology, Volume 22(6), pp. 505512

Da Silva Santos, F.M., da Silva, A.I.M., Vieira, C.B., de Araújo, M.H., da Silva, A.L.C., das Graças Carneiro-da-Cunha, M., de Souza Bezerra, R., 2017. Use of Chitosan Coating in Increasing the Shelf Life of Liquid Smoked Nile tilapia (Oreochromis niloticus) fillet. Journal of Food Science and Technology, Volume 54(5), pp. 1304-1311

Dhaneswara, D., Fatriansyah, J.F., Situmorang, F.W., Haqoh, A.N., 2020. Synthesis of Amorphous Silica from Rice Husk Ash: Comparing $\mathrm{HCl}$ and $\mathrm{CH}_{3} \mathrm{COOH}$ Acidification Methods and Various Alkaline Concentrations. International Journal of Technology, Volume 11(1), pp. 200-208

Faisal, M., Gani, A., 2018. The Effectiveness of Liquid Smoke Produced from Palm Kernel Shells Pyrolysis as a Natural Preservative in Fish Ball. International Journal of Geomate, Volume 15(47), pp. 145-150

Faisal, M., Gani, A., Mulana, F., 2019. Preliminary Assessment of the Utilization of Durian Peel Liquid Smoke as a Natural Preservative for Mackerel [version 6; peer review: 2 approved], F1000Research 2019, Volume 8(240), pp. 1-19

Faisal, M., Gani, A., Husni., Daimon, H., 2017. A Preliminary Study of the Utilization of Liquid Smoke from Palm Kernel Shells for Organic Mouthwash. International Journal of GEOMATE, Volume 13(37), pp. 116-120 
Geng, J.T., Takahashi, K., Kaido, T., Kasukawa, M., Okazaki, E., Osako, K., 2019. Relationship among pH, Generation of Free Amino Acids, and Maillard Browning of Dried Japanese Common Squid Todarodes pacificus meat. Food Chemistry, Volume 283, pp. 324-330

Ginayanti, L., Faisal, M., Suhendrayatna., 2015. Utilization of Liquid Smoke from Pyrolysis of Palm Oil Shell as a Natural Preservative of Tofu. Jurnal Teknik Kimia USU. Volume 4(3), pp. 7-11

Hanafiah, M., Faisal, M., Machdar, I., 2018. Potential Utilization of Liquid Smoke Modified Chitosan as an Antimicrobial Edible Coating for Meat Preservation. Jurnal Teknik Kimia USU, Volume 7(2), pp. 6-11

Hernandez-Munoz, P., Almenar, E., Del Valle, V., Velez, D., Gavara, R., 2008. Effect of Chitosan Coating Combined with Postharvest Calcium Treatment on Strawberry (Fragariax ananassa) Quality During Refrigerated Storage. Food Chemistry, Volume 110(2), pp. 428-435

HPS, A.K., Saurabh, C.K., Adnan, A.S., Fazita, M.N., Syakir, M.I., Davoudpour, Y., Rafatullah, M., Abdullah, C.K., Haafiz, M.K.M., Dungani, R., 2016. A Review on Chitosan-cellulose Blends and Nanocellulose Reinforced Chitosan Biocomposites: Properties and their Applications. Carbohydrate Polymers, Volume 150, pp. 216-226

Idamayanti, D., Purwadi, W., Bandanadjaja, B., Triadji, R., 2020. Rice Husk Waste as an Exothermic Material for a Riser Sleeve for Steel Casting. International Journal of Technology, Volume 11(1), pp. 71-80

Indonesian National Standard, 2008. Quality of Carcass and Beef. The National Standardization Agency of Indonesia

Jinadasa, B.K.K.K., 2014. Determination of Quality of Marine Fishes based on Total Volatile Base Nitrogen Test (TVB-N). Nature and Science, Volume 5(12), pp. 106-111

Kanatt, S.R., Chander, R., Sharma, A., 2008. Chitosan and Mint Mixture: A New Preservative for Meat and Meat Products. Food Chemistry, Volume 107(2), pp. 845-852

Kumar, K.S., Chrisolite, B., Sugumar, G., Bindu, J., Venkateshwarlu, G., 2018. Shelf Life Extension of Tuna Fillets by Gelatin and Chitosan Based Edible Coating Incorporated with Clove Oil. Fishery Technology, Volume 55(2018), pp. 104-113

Kusrini, E., Arbianti, R., Sofyan, N., Abdullah, M.A.A., Andriani, F., 2014. Modification of chitosan by using Samarium for Potential Use in Drug Delivery System. Spectrochimica Acta Part A: Molecular and Biomolecular Spectroscopy, Volume 120, pp. 77-83

Kusrini, E., Shiong, N.S., Harahap, Y., Yulizar, Y., Arbianti, R., Pudjiastuti, A.R., 2015. Effects of Monocarboxylic Acids and Potassium Persulfate on Preparation of Chitosan Nanoparticles. International Journal of Technology, Volume 6(1), pp. 11-21

Morachis-Valdez, A.G., Gómez-Oliván, L.M., García-Argueta, I., Hernández-Navarro, M.D., Díaz-Bandera, D., Dublán-García, O., 2017. Effect of Chitosan Edible Coating on the Biochemical and Physical Characteristics of Carp Fillet (Cyprinus carpio) Stored at $-18^{\circ} \mathrm{C}$. International Journal of Food Science, Volume 2017, pp. 1-5

Ojagh, S.M., Rezaei, M., Razavi, S.H., Hosseini, S.M.H., 2010. Development and evaluation of a Novel Biodegradable Film Made from Chitosan and Cinnamon Essential Oil with Low Affinity Toward Water. Food Chemistry, Volume 122(1), pp. 161-166

Pearson, D., 1968. Assessment of Meat Freshness in Quality Control Employing Chemical Techniques: A Review. Journal of the Science of Food and Agriculture, Volume 19(7), pp. 357-363

Pérez-Córdoba, L.J., Norton, I.T., Batchelor, H.K., Gkatzionis, K., Spyropoulos, F., Sobral, P.J., 2018. Physico-chemical, Antimicrobial and Antioxidant Properties of Gelatin-chitosan Based Films Loaded with Nanoemulsions Encapsulating Active Compounds. Food Hydrocolloids, Volume 79, pp. 544-559 
Pratama, Y., Abduh, S.B.M., Legowo, A.M., Hintono, A., 2019. Effect of Chitosan-palm Olein Emulsion Incorporation on Tapioca Starch-based Edible Film Properties. International Food Research Journal, Volume 26(1), pp. 203-208

Purba, R., Suseno, H.S., Izaky, F.A., Muttaqin, S., 2014. Application of Liquid Smoke and Chitosan as Natural Preservatives for Tofu and Meatballs. International Journal of Applied Science and Technology, Volume 4(2), pp. 212-217

Rakshit, M., Ramalingam, C., 2013. Gum acacia Coating with Garlic and Cinnamon as an Alternate, Natural Preservative for Meat and Fish. African Journal of Biotechnology, Volume 12(4), pp. 406-413

Ramadhansyah, P.J., Bakar, B.H.A., Azmi, M.J.M., Ibrahim, M.H.W., 2011. Engineering Properties of Normal Concrete Grade 40 Containing Rice Husk Ash at Different Grinding Times. International Journal of Technology, Volume 2(1), pp. 10-19

Robledo, N., López, L., Bunger, A., Tapia, C., Abugoch, L., 2018. Effects of Antimicrobial Edible Coating of Thymol Nanoemulsion/Quinoa protein/Chitosan on the Safety, Sensorial Properties, and Quality of Refrigerated Strawberries (Fragariax ananassa) Under Commercial Storage Environment. Food and bioprocess technology, Volume 11(8), pp. 1566-1574

Roller, S., Sagoo, S., Board, R., O’mahony, T., Caplice, E., Fitzgerald, G., Fogden, M., Owen, M., Fletcher, H., 2002. Novel Combinations of Chitosan, Carnocin and Sulphite for the Preservation of Chilled Pork Sausages. Meat Science, Volume 62(2), pp. 165-177

Sabbah, M., Di Pierro, P., Cammarota, M., Dell'Olmo, E., Arciello, A., Porta, R., 2019. Development and Properties of New Chitosan-based Films Plasticized with Spermidine and/or Glycerol. Food Hydrocolloids, Volume 87, pp. 245-252

Saloko, S., Darmadji, P., Setiaji, B., Pranoto, Y., 2014. Antioxidative and Antimicrobial Activities of Liquid Smoke Nanocapsules using Chitosan and Maltodextrin and its Application on Tuna Fish Preservation. Food Bioscience, Volume 7, pp. 71-79

Shariatinia, Z., 2018. Carboxymethyl Chitosan: Properties and Biomedical Applications. International journal of Biological Macromolecules, Volume 120, pp. 1406-1419

Siripatrawan, U., Vitchayakitti, W., 2016. Improving Functional Properties of Chitosan Films as Active Food Packaging by Incorporating with Propolis. Food Hydrocolloids, Volume 61, pp. 695-702

Souza, B.W., Cerqueira, M.A., Ruiz, H.A., Martins, J.T., Casariego, A., Teixeira, J.A., Vicente, A.A., 2010. Effect of Chitosan-based Coatings on the Shelf Life of Salmon (Salmo salar). Journal of Agricultural and Food Chemistry, Volume 58(21), pp. 11456-11462

Szymanska, E., Winnicka, K., 2015. Stability of Chitosan-A Challenge for Pharmaceutical and Biomedical Applications. Marine Drugs, Volume 13(4), pp. 1819-1846

Tosati, J.V., de Oliveira, E.F., Oliveira, J.V., Nitin, N., Monteiro, A.R., 2018. Light-activated Antimicrobial Activity of Turmeric Residue Edible Coatings Against Crosscontamination of Listeria innocua on Sausages. Food Control, Volume 84, pp. 177-185

Usman, A., Kusrini, E., Widiantoro, A.B., Hardiya, E., Abdullah, N.A., Yulizar, Y., 2018. Fabrication of Chitosan Nanoparticles Containing Samarium Ion Potentially Applicable for Fluorescence Detection and Energy Transfer. International Journal of Technology, Volume 9(6), pp. 1112-1120

Valencia-Sullca, C., Atarés, L., Vargas, M., Chiralt, A., 2018. Physical and Antimicrobial Properties of Compression-molded Cassava Starch-chitosan Films for Meat Preservation. Food and Bioprocess Technology, Volume 11(7), pp. 1339-1349

Vásconez, M.B., Flores, S.K., Campos, C.A., Alvarado, J., Gerschenson, L.N., 2009. Antimicrobial Activity and Physical Properties of Chitosan-tapioca Starch Based Edible Films and Coatings. Food Research International, Volume 42(7), pp. 762-769 
Xiao, C., Zhu, L., Luo, W., Song, X., Deng, Y., 2010. Combined Action of Pure Oxygen Pretreatment and Chitosan Coating Incorporated with Rosemary Extracts on the Quality of Fresh-cut Pears. Food Chemistry, Volume 121(4), pp. 1003-1009

Yi, D.Y., Siddique, B.M., Lai, J.C., 2018. Development of Biopolymer Film with Different Ratios of Gelatine to Chitosan Reinforced with Zinc Oxide Nanoparticles for Food Covering/Preservation. In: IOP Conference Series: Materials Science and Engineering, Volume 429(1)

Zhou, G.H., Xu, X.L., Liu, Y., 2010. Preservation Technologies for Fresh Meat-A Review. Meat Science, Volume 86(1), pp. 119-128 